\title{
The Effect of Experiential Learning and Adversity Quotient on Problem Solving Ability
}

\section{Mifta Hulaikah}

Instructional Technology, Graduate School, Universitas Negeri Malang, Indonesia, mifta.hulaikah.1601219@students.um.ac.id

\section{Nyoman Sudana Degeng}

Instructional Technology, Graduate School, Universitas Negeri Malang, Indonesia, nyoman.sudana.d.fip@um.ac.id

\section{Sulton}

Instructional Technology, Graduate School, Universitas Negeri Malang, Indonesia, sulton.fip@um.ac.id

\section{F. Danardana Murwani}

Business \& Management Education, Graduate School, Universitas Negeri Malang, Indonesia, f.danardana.fe@um.ac.id

This study examined the effect of experiential learning and the adversity quotient in the problem-solving ability of accounting vocational college students. The subjects were 120 participants selected and assigned to control and experimental groups. The experimental group was given experiential learning with four steps. Learners participated in a concrete experience (do), reflected on that experience and other information (reflect), developed theories based on experiences and knowledge (think), and formulated a conclusion or solved a problem (apply). The control group was given direct instruction to learning. The data were collected through two instruments, a questionnaire of Student Adversity Quotient Profile (SAQP) and rubrics of problem-solving by Polya. The data were analyzed by using two ways ANOVA, the results were the problem-solving ability of students taught by experiential learning was different from the ones taught by direct instruction, the students' problem-solving ability differed between high and low adversity quotients, and there were interactions between experiential learning and adversity quotients that improved students' problem-solving ability. The steps in experiential learning are a holistic learning process.

Keywords: experiential learning, adversity quotient, problem-solving ability, vocational college, accounting, learning approach

Citation: Hulaikah, M., Degeng, I. N. S., Sulton, \& Murwani, F. D. (2020). The Effect of Experiential Learning and Adversity Quotient on Problem Solving Ability. International Journal of Instruction, 13(1), 869-884. https://doi.org/10.29333/iji.2020.13156a 


\section{INTRODUCTION}

The ability to solve problems is one skill required by the accountant as proficiency needed (Fouche \& Kgapola, 2016; Klibi \& Oussii, 2013). Problem-solving ability is the basic process for identifying problems, considering options, and making informed choices (Greenstein, 2012). This could be considered by employers as key criteria of freshly graduated recruitment. Employers are more interested in motivated graduates who are able to solve real problems following a large capacity of communication and analysis (Fouche \& Kgapola, 2016; Klibi \& Oussii, 2013; Riczqi, Putri, \& Harto, 2012; Hunton, 2002). There are four steps to the problem-solving process by Polya (1973): understanding the problems fully, devising a plan, carrying out the plan and looking back at the solution.

Skills to solve a problem of accounting vocational college differ from the university level. Learning in vocational education is not similar to learning in general education (Jalinus \& Nabawi, 2019). The vocational or educational technique students program focus on compromising problems due to the career world. Solving a problem related on the conditions which accounting works is needed by vocational college (Kendirli, Ulker, \& Yamaltdinova, 2015), that is why vocational college need a learning approaches which have characteristics such as complex activity, link from classroom to real-life activities and involve more senses (hearing, seeing, touching, feeling and testing) (Engr. Amaechi \& Thomas, 2016). It is more advantages to bring the instructional approaches which aimed to give real-life and business experiences on vocational students (Villiers, 2010).

It has become clear that accounting education mostly used direct instruction or learning based on teacher's explaining (Kendirli, Ulker \& Yamaltdinova, 2015). The direct instruction is a skill-based instructional technique that uses for promoted sequential development of students' competencies following a scripted instructional routine and providing praise inappropriate time (Joyce \& Weil, 2000). The key to direct instruction relies on the quality of the teacher's presentation and frequency of practice (Eggen \& Kauchak, 2012). Learning result was taken from teacher and textbooks, which it is not related to real-life and job (Chiang \& Lee, 2016).

The learning approach which can facilitate the characteristic of vocational college and improve a problem-solving ability is known as experiential learning. Experiential learning was developed by Kolb (1984). Learning is the process by which knowledge is created through the transformation of experience and knowledge resulting from the combination of grasping and transforming experience (Kolb, 1984). Experiential learning makes learners memorize what they hear and what they do (Smart \& Csapo, 2007). It can facilitate the learners to make a link between theory and real-world applications, motivation, and retention of learning. Learners participate in a concrete experience (do), reflect on that experience and other information (reflect), develop theories based on experiences and knowledge (think), and formulate a conclusion or solve a problem (apply). It is important to emphasize the role of experience in solving problems (Bernik \& Žnidaršič, 2012). The students are mainly believed that experiences are sources of their knowledge to analyze and solve problems through the combination 
of theories and practices (Hawtry, 2007; Brickner \& Etter, 2008; Bernik \& Žnidaršič, 2012). Learning result was taken from not only textbooks or teachers, but also synergetic transaction between person and environment.

Some studies on how experiential learning improves problem-solving ability were done, such as by Efstratia (2014) which concluded that through experiential learning, connection problem with real-world is achieved. This study stated that experiential learning by giving a project was effective in teaching problem-solving. The students stimulated by driving questions first and engaging them into a compelling project. They learned how to solve a problem throughout the process of this project. There were not classified the activity in each step of reflective observation, abstract conceptualization, and active experimentation. Similar to, Pugsley \& Clayton (2018) used a mini project, critique, and discussion as an experiential learning activity to improving problemsolving ability.

There was so many activities which included in each step of experiential learning. Svinicki \& Nancy (1987); Hagan (2012), listed the activity that for each step on experiential learning. The activities showed in table 1.

Table 1

Experiential Learning's Activity

\begin{tabular}{|c|c|}
\hline Steps & Activity \\
\hline Concrete Experience & $\begin{array}{l}\text { Laboratories, Observations, Primary Text Reading, Simulations/ } \\
\text { Games, Field Work, Trigger Films, Readings, Problem Sets, } \\
\text { Examples, case studies, living case studies, internships, job } \\
\text { shadowing }\end{array}$ \\
\hline Reflective Observation & $\begin{array}{l}\text { Logs, Journal, Discussions, Brainstorming, Thought questions, } \\
\text { Rhetorical Questions }\end{array}$ \\
\hline $\begin{array}{l}\text { Abstract } \\
\text { Conceptualization }\end{array}$ & Lecture, Papers, Model Building, Project, Analogies \\
\hline Active Experimentation & $\begin{array}{l}\text { Simulations, Case study, Laboratory, Fieldwork, Projects, } \\
\text { Homework }\end{array}$ \\
\hline
\end{tabular}

Students also need confidence, great minds, and resilience to survive the problems. This is what is known as adversity quotient. Adversity quotient is the ability to withstand and surmount life problems and challenges (Espanola, 2006). Adversity quotient was developed by Stoltz (1997). He stated that the other factor of success in learning, besides Intellectual Quotient (IQ) and Emotional Quotient (EQ) is Adversity Quotient (Stoltz, 1997; Pangma, Tayraukham \& Nuangchalerm, 2009). The four dimensions of adversity quotient are: control, related to the extent to which there is control over the difficulties experienced; origin and ownership, answering the question about who or what is the origin of the problem? The extent to which the source of difficulty is acknowledged; reach, answering the question to what extent the difficulties will affect other aspects of life?; endurance, answering the old question of how long will this problem will last? (Stoltz, 1997). The positive relationship between adversity quotient and the process of problem-solving was related to "reach" factor (Parvathy \& Praseeda, 2014). Al-Kumayi (2006) stated that if a person has a high adversity quotient, he will be 
able to overcome difficulties and can survive with no despair in addressing the problem. Adversity quotient is also important for vocational graduates to prepare themselves to involve in the working field in the future and to achieve the academic performance (Matore, Khairani \& Razak, 2015; Vinas \& Aquino-malabanan, 2015).

Adversity quotient will perform optimally when the students facing adversity or difficult thing (Hema \& Gupta, 2015). Through experiential learning, most of the students change their personality and increase their level of optimism. The students can cope successfully with adversity and believe that negative events are temporary, limited in scope and manageable even when receiving poor grades on exams or projects (Sheimaili, 2013). Experiential learning allows exploring those skill through its step. Adversity has an important role to keep students always active. When students take an active role in the learning process the student's learning is optimized (Smart \&Csapo, 2007). The students with high adversity quotient will be sure that they can handle the problems on experiential learning, quickly.

The difference of this study from others is this study combined four steps of experiential learning: concrete experience, reflective observation, abstract conceptualization, and active experimentation. The other study mostly used one activity such as project or case study as concrete experience only, without activity for reflection, even build an abstract concept. Therefore, it is necessary to bring all steps of experiential learning and adversity quotient in achieving the problem-solving ability of vocational students. The research questions of this study are:

1. Is there any significant difference in student's problem-solving ability between those who learn with experiential learning and those who learn with direct instruction?

2. Is there any significant difference between the students who have high and low adversity quotient on student's problem-solving ability?

Is there any significant interaction between experiential learning and adversity quotient on student's problem-solving ability?

\section{METHOD}

\section{Research Design}

This research applied a quasi-experimental approach with a post-test only. The control class was taught by direct instruction to learning, while the experimental class was taught by experiential learning. The adversity quotient student was a moderator variable where problem-solving was a dependent variable. The Adversity quotient of the students was assessed before the learning process occurred. After each type of learning approach was completed, the problem-solving ability of each student was assessed.

\section{Subjects}

This study involved 120 participants of third grade from one of diploma vocational college in Indonesian, with subject matter Accounting Information Systems. The sampling was cluster random sampling. Two classes were treated as experimental group 
and the other two as a control group, consisting of 60 students each. To ensure the similarity between groups, we compared the score of the prerequisite course.

\section{Data Collecting and Research Instrument}

The data collection procedure was conducted in two steps. First, before learning approaches were taken, the student's adversity quotient was collected by questionnaire. The student adversity quotient instrument used in this research was adapted from Stoltz (1997) and Bakare (2015). The questionnaire is entitled Student Adversity Quotient Profile (SAQP) consisting of 20 statements in negative condition because adversity quotient assesses how well the students can handle negative situations. The five-point Likert-scale was used ranging from strongly disagree to strongly agree. SAQP consists of four indicators of adversity quotient. Control is related to the extent the subjects felt responsible for improving the situations. Origin ownership is related to what extent the students handled the situations. Reach is related to how far the situations affected other aspects, and Endurance is related to how long the effects of the situations lasted. To score SAQP, it multiplies the total score on four indicators, so there is 200 for maximum score and 0 for the minimum score (Bakare, 2015). Each class, for experimental and control, were divided into two groups of students which were those who have high adversity quotients (above average), and those with low adversity quotients (below average). Based on the validity and reliability test, the questionnaire was valid and reliable (Cronbach's Alpha 0,851).

Second, the student's problem-solving ability was collected by administering four case study test at the last step of experiential learning (active experimentation) to the experimental class, while the control class was given the test at the end of the learning process. The case study then scoring by a rubric, which comprised by using indicators for problem-solving based on Polya steps (1973). The following Table 2 is the developed problem-solving skill rubric:

Table 2

The Rubric of Problem-Solving Ability (Adapted from Polya)

\begin{tabular}{llll}
\hline No. & Indicator & Statement & Skor \\
\cline { 3 - 4 } 2 & Understand the problem & $\begin{array}{l}\text { Clearly described a problem with } \\
\text { supporting detail to the situation }\end{array}$ & $1-4$ \\
2 & Devising a plan & $\begin{array}{l}\text { Listed the full range of steps and strategies } \\
\text { to solve a problem }\end{array}$ & $1-4$ \\
3 & Carry out the plan & $\begin{array}{l}\text { Structured the strategy in the previous step } \\
\text { to be a whole solution } \\
\text { Checked and revised the solutions }\end{array}$ & $1-4$ \\
4 & Looking back & Chel-4 \\
\hline
\end{tabular}

\section{Treatment}

The control class was taught with direct instruction while the experimental class was taught by experiential learning. the time allocation for each class was 4 x 55 minutes. The activity of experiential learning in each step was adopted and developed from Butler, Church, \& Spencer (2019). The experiential learning activities performed in this study is presented in the following table 3 . 
Table 3

Student's Activity on Experimental Class

\begin{tabular}{|c|c|c|}
\hline Steps & Activity & Student's Activity \\
\hline $\begin{array}{l}\text { Concrete } \\
\text { Experience }\end{array}$ & Observation & $\begin{array}{l}\text { Observing the process of sales and cash receipt of the business } \\
\text { unit of this college } \\
\text { Observing in teams what the documents that were needed for the } \\
\text { process of sales and cash receipt and how to process them. } \\
\text { Observing in teams what the department on it. } \\
\text { The students practiced their own guided by the manager or } \\
\text { employee, on how selling and cash receiving in this unit business, } \\
\text { included preparing the documents. }\end{array}$ \\
\hline $\begin{array}{l}\text { Reflective } \\
\text { Observation }\end{array}$ & Brainstorming & $\begin{array}{l}\text { Discussing in teams the sales and cash receipt system based on } \\
\text { experience. Discussing what documents and departments used. } \\
\text { Presentation of the discussion result. } \\
\text { Receiving critiques and recommendations from other teams } \\
\text { Building a concept and conclusion about the sales and cash receipt } \\
\text { system based on experience and team discussion }\end{array}$ \\
\hline $\begin{array}{l}\text { Abstract } \\
\text { Conceptualization }\end{array}$ & Paper & $\begin{array}{l}\text { Finding the theory about how the sales and cash receipt system by } \\
\text { reading a book or journal. } \\
\text { The students looking the right theory about what documents, what } \\
\text { departments and how the flow chart of the system. } \\
\text { Evaluating the concept, by integrating the experience and its } \\
\text { reflection. The students compared their answer, which resulted } \\
\text { from direct experience and read a book. The students evaluated } \\
\text { their experience. } \\
\text { Creating a conclusion about sales and cash receipt system by } \\
\text { drawing a flowchart as a paper (on this step, the real knowledge is } \\
\text { created) }\end{array}$ \\
\hline $\begin{array}{l}\text { Active } \\
\text { Experimentation }\end{array}$ & Case Study & $\begin{array}{l}\text { Applying the created knowledge to a new problem by answering a } \\
\text { case study }\end{array}$ \\
\hline
\end{tabular}

\section{Data Analysis}

In this study, descriptive statistics were used to analyze the characteristics of participants and the level of students' problem solving and adversity quotient. The hypothesis was analyzed using two-way ANOVA with a $2 \times 2$ factorial design. There is three hypotheses of the research: the student's problem solving differs between the students taught by experiential learning than those are taught using direct instruction to learning, the student's problem solving differs between high adversity quotient and low adversity quotient, and there is interaction between learning approach with adversity quotient in student's problem solving.

\section{FINDINGS AND DISCUSSION}

From the results of descriptive statistic, the average mean of the problem-solving ability of the experimental class taught using experiential learning experienced higher achievement than that of the control class taught using direct instruction for learning. The average mean problem-solving ability of students in the experimental class was 39 , 40 with a standard deviation of 4,16 , the average mean of adversity quotient was 137 , 47 , while for the control class the average mean of problem-solving ability was 34,47 with a standard deviation of 3,19 and average mean adversity quotient was 137,03 . The descriptive statistic has shown in table 4. 
Table 4

Descriptive Statistics of Problem-Solving Ability and Adversity Quotient

\begin{tabular}{lllll}
\hline Learning Outcome & Group & N & Mean & Std. Dev. \\
\hline Problem Solving Ability & Experiential Learning & 60 & 39,40 & 4,16 \\
& Direct Instruction & 60 & 34,47 & 3,19 \\
\hline Adversity Quotient & Experiential Learning & 60 & 137,47 & 13,64 \\
& Direct Instruction & 60 & 137,03 & 11,01 \\
\hline
\end{tabular}

Each class was divided into two groups of students which were those who have high adversity quotients ( $\geq 137,15$ or above average), and those with low adversity quotients (< 137,15 or below average). In the experimental class, 32 participants had high adversity quotients and 28 participants had low adversity quotients. In the control class, 29 participants possessing high adversity quotients and 31 participants with low ones.

One-Sample Kolmogorov Smirnov test showed significance 0,153, while Levene's test showed 0,294 . The value was $>0,05$, so the data were normal and homogeneous. After testing the normality and homogeneity, the hypothesis testing was performed. ANOVA statistical test results are shown in Table 5.

Table 5

Result of ANOVA

\begin{tabular}{llllll}
\hline \multicolumn{2}{l}{$\begin{array}{l}\text { Tests of Between-Subjects Effects } \\
\text { Dependent Variable: Problem Solving Ability }\end{array}$} & & & & \\
\hline Source & $\begin{array}{l}\text { Type III Sum of } \\
\text { Squares }\end{array}$ & df & $\begin{array}{l}\text { Mean } \\
\text { Square }\end{array}$ & F & Sig. \\
\hline Corrected Model & $963.198^{\text {a }}$ & 3 & 321.066 & 26.750 & .000 \\
Intercept & 162740.583 & 1 & 162740.583 & $1.356 \mathrm{E} 4$ & .000 \\
Learning Approaches & 686.284 & 1 & 686.284 & 57.179 & .000 \\
$\begin{array}{l}\text { Adversity Quotient } \\
\text { Learning Approaches * }\end{array}$ & 172.023 & 1 & 172.023 & 14.333 & .000 \\
Adversity Quotient & 61.384 & 1 & 61.384 & 5.114 & .026 \\
Error & 1392.269 & 116 & 12.002 & & \\
Total & 166044.000 & 120 & & & \\
Corrected Total & 2355.467 & 119 & & & \\
a. R Squared =.409 (Adjusted R Squared =.394) & & & & \\
\hline
\end{tabular}

Based on table 5 shows there was: 1) significant difference between problem solving abilities of students taught by experiential learning and direct instruction learning, with a significance value of $<0.05(0.00)$; 2) significant difference in terms of problem solving ability of students who had high adversity quotient and low adversity quotient, with significance value of $<0.05(0.00) ; 3)$ there was interaction between experiential learning and adversity quotient on problem solving ability which a significance value of $<0.05$ (0.026). Because there was a significant difference, therefore the post-hoc test was applied. 
Table 6

Post-Hoc Test for Problem-Solving Ability Across the Learning Approaches

\begin{tabular}{lllll}
\hline Dependent Variable: Problem Solving Ability & & & \\
\hline (I) Learning Approaches & (J) Learning Approaches & $\begin{array}{l}\text { Mean Difference } \\
\text { (I-J) }\end{array}$ & $\begin{array}{l}\text { Std. } \\
\text { Error }\end{array}$ & Sig. $^{\text {at }}$ \\
\hline Experiential Learning & Direct Learning & $4.790^{*}$ & .633 & .000 \\
Direct Learning & Experiential Learning & $-4.790^{*}$ & .633 & .000 \\
*. The mean difference is significant at the .05 level. & & & \\
\hline
\end{tabular}

From table 6 , the significance value was 0,00 with mean difference 4,790 between two learning approaches. This result supporting the ANOVA that there was a significant difference in the problem-solving ability of students taught by experiential learning and direct instruction learning. The post-hoc for problem-solving ability across the level of adversity quotient was applies in table 7.

Table 7

Post-Hoc Test for Problem-Solving Ability Across the Adversity Quotient Dependent Variable: Problem Solving Ability

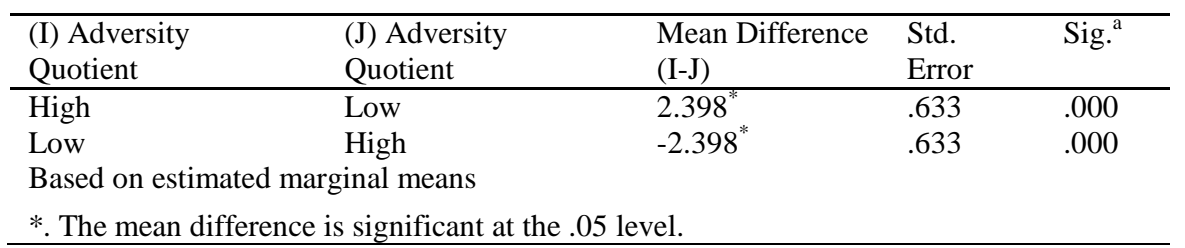

From table 7 , the significance value was 0,00 with a mean difference of 2,398 . It means that there was a significant difference in problem-solving ability of student's problemsolving ability between high adversity quotient and low adversity quotient.

Plot-interaction effect between experiential learning and adversity quotient on student's problem-solving ability showed that there was no parallel line but also not cut each other. It could be reflected that there was significant interaction between learning approaches and adversity quotient on problem-solving ability, but there was just a little interaction.

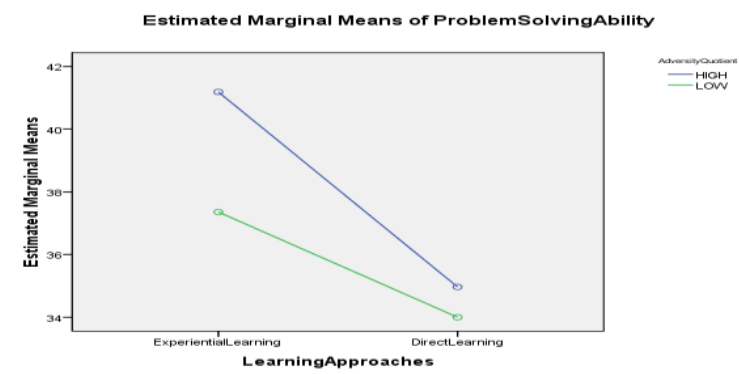

Figure 1

Interaction between Experiential Learning and Adversity Quotient on Problem-Solving Ability 


\section{The Effect of Experiential Learning on Problem Solving Ability}

Data analysis showed that there was a significant difference in student's problem-solving ability between the students who taught by experiential learning and direct instruction learning. The student's problem-solving ability taught by experiential learning is higher than direct instruction learning. It means that experiential learning effectively enhanced the student's problem-solving ability more than that of direct instruction. There was a holistic process in experiential learning which allowed students to identify, clarify, and keep focused on their problem. Each step in experiential learning provides a different problem. For example, in this research, the lecturer gave the problem of how the sales and cash receipt system process of the local business. Figure 2 showed that students involved either directly (practicing) or indirectly (observing) of the system, which called the concrete experience step. As a result of this step, the observation sheet about all information was collected, like documents and departments needed.

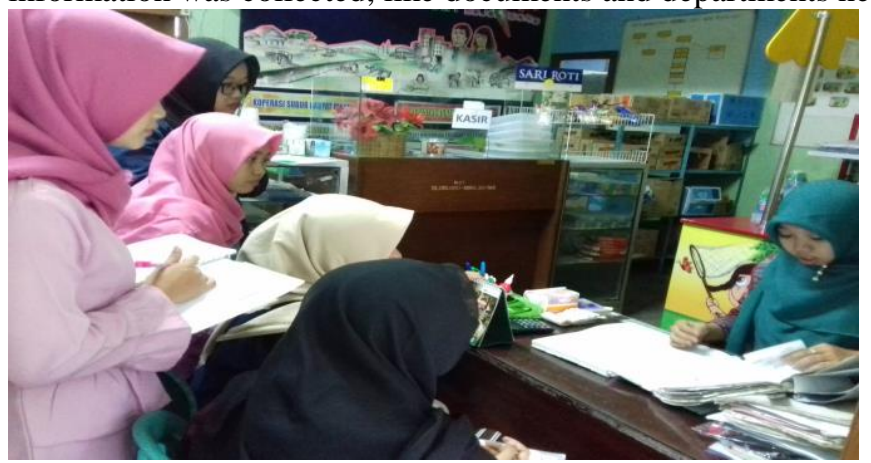

Figure 2

Students Observe Actual Sales and Cash Receipt System at a Local Business (Concrete Experience)

In the second stage, reflective observation, students were asked and analyzed to discuss their observation of past experience by a team and another team. They viewed the experience from different perspectives, then checked and corrected it based on another suggestion. The third stage, abstract conceptualization, students asked to find out the theory about sales and cash receipt system by reading a book. They should be able to combine two different things, i.e. the experience and knowledge obtained from theoretical sources, into one unified whole knowledge appropriately. Students can conclude on how the concept of sales and cash receipt system as a result of this stage. The last stage, active experimentation, students applied the created knowledge to solve a case study.

The presence of different problems at each stage gives more experience for students in solving a problem. The effectiveness of students in solving the problem relatives to their perspective of experiences and how much they face the problem (Carson, 2007). To be successful in learning, especially in solving problems, students use their experiences (Fitri, 2017). They search from many viewpoints about the problem before attempting to solve it. 
On the other hand, the direct instruction made students are more passive than in experiential learning because it does not allow to experiment actively with their own conclusions. Experiential learning refers to the involvement of students in an actual activity to enable them to experience what they learned and have the opportunity to reflect on what they learned from the activity (Silberman, 2007). This result supports the research done by Efstratia (2014) \& Pugsley \& Clayton (2018).

\section{The Effect of Adversity Quotient on Problem Solving Ability}

There was a significant difference in problem-solving ability between the student who has high adversity quotient and the students who have a low adversity quotient. Based on the results of the study, the students with high adversity quotient are higher than the low ones. The students with high adversity quotient and low have a different pattern in solving a problem. The students with high adversity quotient described the problem clearly, listed all the possible steps to answer, and arranged the steps to be the right solution. They also looked back on their answers. Students with high adversity quotient get more score in problem-solving. The results of students' answers to the high adversity quotient in problem-solving can be seen in figure 3 .

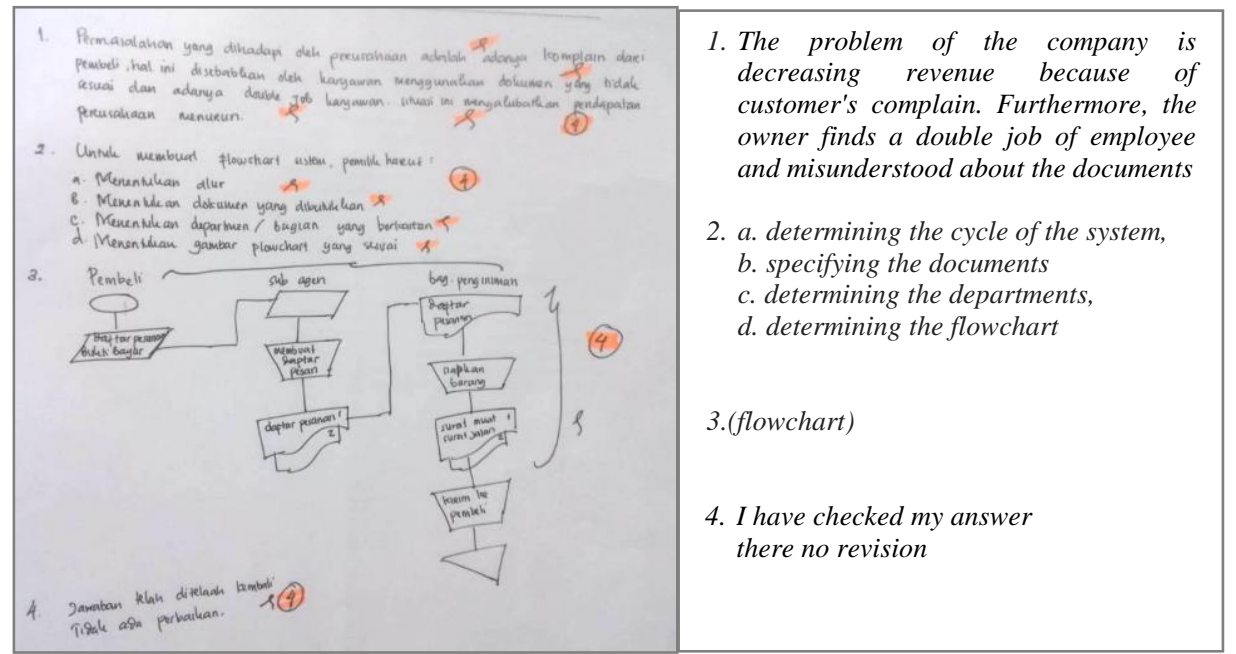

Figure 3

The Sample Results of the Student with High Adversity Quotient on Problem-Solving

While the students with low adversity quotient only described the main problem without further explanation about the cause and effect. In devising a plan step, they listed the strategy to solve the problem, but only a few were corrected. They also less able to combine all the information to solve the problem. The students with low adversity quotient have no checked their answers. They were satisfied with their answer, without checking at all. The results of students' answers to the low adversity quotient category in problem-solving can be seen in figure 4 . 


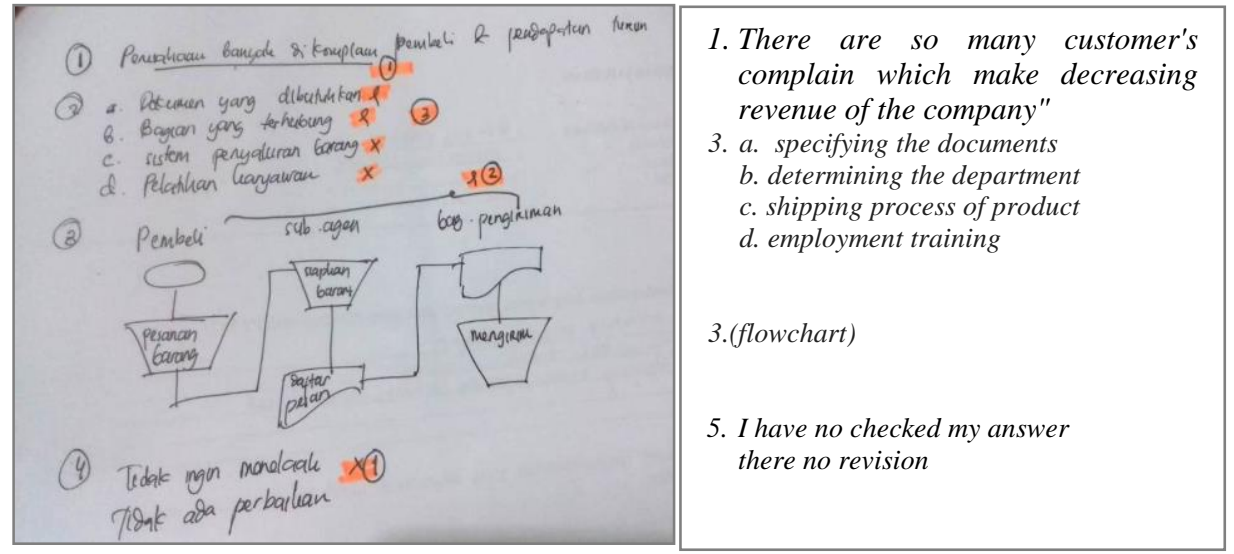

Figure 4

The Sample Results of the Student with Low Adversity Quotient on Problem-Solving

Adversity quotient concerns with someone's resilience to respond to negative situations, including to solve the problems. To arrive at the success of finding answers, students will experience various problems as a barrier in solving the problem, and the students who have adversity quotient above the average will assume a given problem as an opportunity to achieve the goal, and these students will not easily give up to solve a given problem (Sahyar, 2017). Problem-solving is a complex process of thinking skills (Waetjen, 1989). To understand a problem, someone must have the knowledge to solve it (Carson, 2007). The students with high adversity quotient will be able to understand the problem well, determine all information stated and use it to solve a problem (Rinawati, Waluya \& Hartono, 2018; Safitri, Juniati \& Masriyah, 2018). No matter how hard the subject lesson is, they will perform well (Vinas \& Aquino-Malabanan, 2015). The students with low adversity quotient felt quickly satisfied with their achieving, no matter the score is. They attended to give up to understand the knowledge and failed to give a reason about the problem.

\section{The Interaction Effect of Experiential Learning and Adversity Quotient on} Problem Solving Ability

There was significant interaction of experiential learning and adversity quotient on student's problem-solving ability. However, there was little interaction between them. The students who have high adversity quotient, there was a significant difference in problem-solving ability between those who taught by experiential learning and direct instruction learning. For students with high adversity quotient, the problem-solving ability taught by experiential learning is higher than direct instruction learning. While the students who have low adversity quotient, there was a significant difference in problem-solving ability between those who had low adversity quotient who learned through experiential learning and direct instruction learning. Adversity quotient is needed to adapt to the condition, reflect on the experience and handle the problem 
which is shown during case studies at the stages of experiential learning, so the knowledge can be created well. The students used their optimism optimally to finish all steps of experiential learning. The students with a high aspect of reach, will not extend the problem to other life domains. They will be sure that the problem will affect that unique situation only. Endurance refers to the perceived length of time the adversity will last. The students with high endurance will be sure that they can handle the problem quickly. The students are able to cope successfully with adversity and believe that negative events are temporary, limited in scope and manageable even when receiving poor grades on exams or projects (Sheimali, 2013). The accounting profession requires students' problem-solving skills to adapt the complex situations and often rapidly changing the environment (Villiers, 2010). This skill can be enhanced through a learning process and adversity quotient becomes an instrument which affects their thinking and their perspective in how they view problems (Sahyar, 2017; Humami, Mukhadis \& Sumarli, 2014). So, this research affirms that experiential learning and adversity quotients have an important role in improving problem-solving ability.

The application of experiential learning and the adversity quotient in improving the ability of problem-solving, particularly in students in educational institutions would provide advantages for both the graduates and the workplace. Vocational graduates will be more competent, while employers would not require extra time and budgeting to conduct training for new graduates. Problem-solving becomes one of the skills that can be supplied to the vocational graduates facing competition for job seekers.

\section{CONCLUSION}

The results showed that: 1) a significant difference in the problem-solving ability of the students who were taught by experiential learning and direct instruction for learning. The student's problem-solving ability on experiential learning resulted in better performances than direct instruction learning, 2) a significant difference in problemsolving ability of both the students with high and low adversity quotients. The students with high adversity quotients showed better performances than students with low averages of adversity quotients in solving the problem and 3) there was significant interaction between learning approaches and adversity quotients on student's problemsolving ability. The experiential learning improved the student's problem-solving ability on both of the students with high and low adversity quotient. The suggestions for future research, there must be more exploration of other activities adjusted to each step-in experiential learning. There is the holistic process on its steps which can enrich the competencies of vocational graduates related to real-life work.

\section{REFERENCES}

Al-Kumayi, S. (2006). Intelligence 99 (how to reach peace of life through the application of the 99 names of Allah). Jakarta: PT. Mizan.

Bakare, B. M. (2015). Student's adversity quotient and related factors as predictors of academic achievement in the West African senior school certificate examination in Southwestern Nigeria. University of Ibadan. 
Bernik, M. \& Žnidaršič, J. (2012). Solving complex problems with help of experiential learning. Organizacija, 45(3), 117-124.

Brickner, D. R., \& Etter, E. R. (2008). Strategies for promoting active learning in a principles of accounting course. Academy of Education Leadership J., 12(2), 87-93.

Butler, M. G., Church, K. S., \& Spencer, A. W. (2019). Do, reflect, think, apply: Experiential education in accounting. Journal of Accounting Education, 48, 12-21.

Carson, J. (2007). A Problem with problem solving: Teaching thinking without teaching knowledge. The Mathematics Educator, 17(2), 7-14.

Chiang, C. L., \& Lee, H. (2016). The effect of project-based learning on learning motivation and problem-solving ability of vocational high school students. International Journal of Information and Education Technology, 6(9), 709-712.

Efstratia, D. (2014). Experiential education through project based learning. Procedia Social and Behavioral Sciences, 152, 1256-1260.

Eggen, P., \& Kauchak, D. (2012). Strategies and models for teachers: Teaching content and thinking skills. Boston: Pearson

Engr. Amaechi, O. J., \& Thomas, C. G. (2016). Strategies of effective teaching and learning practical skills in technical and vocational training programmes in Nigeria International Journal of Scientific Research Engineering \& Technology (IJSRET), 5, 598-603.

Espanola, R. P. (2016). Adversity quotient (AQ) and academic performance of selected students in Msu Marawi city. Proceedings Journal of Education, Psychology and Social Science Research, 60-66.

Fitri, R. Y. (2017). The effect of problem-based learning model ( PBL ) and adversity quotient (AQ) on problem-solving ability. American Journal of Educational Research, $5(2), 179-183$.

Fouche, J. P., \& Kgapola, M. P. (2016). Professional accountants' perspective of skills required to progress to management positions. International Journal of Business and Management, 8(1), 20-36.

Greenstein, L., (2012). Assessing $21^{\text {st }}$ century skills, A guide to evaluating mastery and authentic learning. London: SAGE Publication.

Hagan, L. M. (2012). Fostering experiential learning and service through client projects in graduate business courses offered online. American Journal of Business Education, 5(5), 623-632.

Hawtry, K. (2007). Using experiential techniques. Journal of Economic Education, Spring, 143-152.

Hema, G., \& Gupta, S. M. (2015). Adversity quotient for prospective higher education. The International Journal of Indian Psychology, 2(3), 49-64. 
Humami, F., Mukhadis, A., \& Sumarli, S. (2014). the effect of numbered heads together (NHT) teaching model and adversity quotient on learning achievement subjects of energy conversion machines. Vocational Technology, 37(2), 119-128.

Hunton, J. E. (2002). Blending information and communication technology with accounting research. Accounting Research, 16(1), 56 - 67.

Jalinus, N., \& Nabawi, R. A. (2019). A comparison of the problem-solving skills of students in PjBL versus CPjBL model: An experimental study. Journal of Technical Education and Training, 1(11), 36-43.

Joyce, B., \& Weil, M. (2000). Models of teaching. Boston, MA: Allyn and Bacon.

Kendirli, S., Ulker, Y., \& Yamaltdinova, A. (2015). accounting education at faculty of economic administrative science in Kyrgyzstan universities and expectation of students from accounting education: A case study in Bishkek. Research Journal of Business and Management., 2(1), $52-68$.

Klibi, M. F., \& Oussii, A. A. (2013). Skills and attributes needed for success in accounting career: Do employers' expectations fit with students' perceptions? Evidence from Tunisia. International Journal of Business and Management, 8(8), 118 - 132.

Kolb, D.A. (1984). Experiential learning: experience as the source of learning and development. Englewood Cliffs, N.J.: Prentice-Hall.

Matore, M. E. E. M., Khairani, A. Z., \& Razak, N. A. (2015). The influence of AQ on the academic achievement among Malaysian polytechnic students. International Education Studies, 8(6), 69-74.

Pangma, R., Tayraukham, S., \& Nuangchalerm, P. (2009). Causal factors influencing adversity quotient of twelfth grade and third-year vocational students. Journal of Social Sciences, 5(4), 466-470.

Parvathy, U., \& Praseeda, M. (2014). Relationship between adversity quotient and academic problems among student teachers. Journal of Humanities and Social Science, 19(11), 23-26.

Polya, G. (1973). How to solve it. Princeton: Princeton University Press.

Pugsley, K. E., \& Clayton, L. H. (2018). Traditional lecture or experiential learning: Changing student attitudes. Journal of Nursing Education, 42(11), 520-523.

Riczqi, T., Putri, S., \& Harto, P. (2012). Persepsi mahasiswa akuntansi dan akuntan pendidik terhadap kompetensi yang dibutuhkan lulusan akuntansi. Diponegoro Journal of Accounting, 1(2), 1-9.

Rinawati, S., Waluya, S. B., \& Hartono. (2018). The analysis of student's problem solving difficulty viewed from adversity quotient on means-ends analysis learning. Unnes Journal of Mathematics Education Research, 1-8. 
Safitri, A. N., Juniati, D., \& Masriyah. (2018). Students' relational understanding in quadrilateral problem solving based on adversity quotient. Journal of Physics, 1-6.

Sheimali, N.B. (2013). Correlation between experiential learning and optimism among college students. dissertation for management leadership and policy. Dubai: The British University in Dubai (BUiD)

Silberman, M. (2007). Handbook experiential learning: Strategi pembelajaran dari dunia nyata. Bandung: Nusamedia

Smart, K. L., \& Csapo, N. (2007) Learning by doing: Engaging students through learner-centered activities. Business Communication Quarterly, 70(4), 451-457.

Stoltz, P. (1997). Adversity quotient: Turning obstacles into opportunities. New York: John Wiley \& Sons,

Svinicki, M. D., \& Nancy M. D. (1987). The kolb model modified for classroom activity. College Teaching, 35(4), 141-146.

Tian, Y., \& Fan, X. (2014). Adversity quotients, environmental variables and career adaptability in student nurses. Journal of Vocational Behavior, 85, 251-25.

Villiers, R. De. (2010). The incorporation of soft skills into accounting curricula: Preparing accounting graduates for their unpredictable futures. Meditari Accounting Research, 1(2), 1-22.

Vinas, D. K. D., \& Aquino-malabanan, M. G. (2015). Adversity quotient and coping strategies of college students in lyceum of the Philippines university. Asia Pasific Journal of Education, Arts and Sciences, 2(3), 68-72.

Voss, J. F., Greene, T. R., Post T. A., \& Penner B. C. (1983). Problem solving skill in the social sciences. In the psychology of learning and motivation: Advances in research and theory. New York: Academic.

Waetjen, W. B. (1989). Technological problem solving: A proposal. Reston, VA: International Technology Education Association.

Yuliati, L., Riantoni, C., \& Mufti, N. (2018). Problem solving skills on direct current electricity through inquiry-based learning with PhET simulations. International Journal of Instruction, 11(4), 123-128. 
Appendix A.

Post-test (Case study)

KARUNIA JAYA is a medicines distributor which promoting their product through television. During the two weeks, there were lots of buyer complaints about the mismanagement of goods. The employees have double jobs and inappropriate documents. This condition makes decreasing of the revenue. After the owner conducts an evaluation, he decides to make a flowchart for ordering the product, cash receiving, and product delivering system.

KARUNIA JAYA sells it's products through sub-agents. Customers send the information about the products ordered and the payment by online, then the sub-agent prepares the product and make an order list documents in two copies. The first copy is sent to the shipping department. The shipping department will prepare the products and make a shipping document.

1. Can you describe the problem clearly?

2. What is the information needed to solve this problem?

3. What is the complete solution to this problem?

4. Check your answer, is there any revision ye made? 